\title{
Penerapan minapadi untuk mendukung ketahanan pangan dalam meningkatkan kesejahteraan masyarakat Desa Koto Benai Kabupaten Kuantan Singingi
}

\author{
Eni Sumiarsih*1, Kausar ${ }^{1}$, Adriman $^{1}$, Eddiwan $^{1}$, dan Ika Fitria Hasibuan ${ }^{2}$ \\ ${ }^{1}$ Universitas Riau \\ ${ }^{2}$ Sekolah Tinggi Pariwisata Riau \\ * enisaf@yahoo.co.id
}

\begin{abstract}
Abstrak. Desa Koto Benai merupakan desa yang sebagian penduduknya bermata pecaharian dibidang pertanian. Masyarakat Desa Koto Benai menanam tanaman padi hanya 2 kali dalam satu tahun. Minapadi merupakan cara pemeliharaan ikan di sela-sela tanaman padi, Ini merupakan salah satu teknologi tepat guna pada lahan sawah. Jenis ikan yang dapat dipelihara pada sistem tersebut adalah ikan mas, nila, mujair, lele, dan lain-lain. Tujuan dilakukannya kegiatan pengabdian ini adalah supaya para petani dapat memahami teknik pemiliharaan ikan dengan sistem minapadi, diharapkan setelah diadakannya pengabdian ini para petani dan masyarakat dapat menerapkan teknologi sistem minapadi ini agar meningkatkan pendapatan petani yang tidak hanya berasal dari hasil pertanian saja dan juga diharapkan akan terwujudnya desa yang mandiri. Metode dalam kegiatan pengabdian ini terdiri dari ceramah dan praktek langsung di lapangan. Pelaksanaan mina padi dilakukan beberapa tahap: tahap analisis situasi dan observasi pendahuluan, pelatihan bercocoktanam mina padi dan budidaya ikan, pembimbingan dan pendampingan minapadi, penentuan ketercapaian indikator kegiatan, dan permasalahan yang timbul. Hasil yang diperoleh dari pelaksanaan kegiatan pengabdian ini adalah masyarakat antusias untuk melaksanakan budidaya mina padi, hasil produksi pertanian dan peternakan meningkat sebesar $24 \%$.
\end{abstract}

Kata kunci: keuntungan; nila; produksi; teknologi

\begin{abstract}
Koto Benai village is a village where most of its inhabitants have eyes in the agricultural sector. The people of Koto Benai Village grow rice only 2 times a year. Mina padi is a way of maintaining fish between rice plants, this is one of the appropriate technologies in paddy fields. The types of fish that can be maintained on the system are carp, tilapia, tilapia, catfish, and others. The purpose of this activity is so that farmers can understand the technique of using fish with the Minapadi system. It is expected that after this service the farmers and the community can apply the Minapadi system technology to increase farmers' income which is not only from agricultural products. independent village. Method in this activity consists of lectures and direct practice in the field. The implementation of rice mina is carried out in several stages: the situation analysis stage and preliminary observations, training in the cultivation of rice mina and fish farming, mentoring and mentoring of rice mina, determining the reliability of activity indicators, and problems that arise. The results obtained from the implementation of this activity were enthusiastic communities to carry out minapadi cultivation, agricultural and livestock production increased in $24 \%$.
\end{abstract}

Keywords: profit; tilapia; production; technology

To cite this article: Sumiarsih, E., Kausar, Adriman, Eddiwan, \& I. F. Hasibuan. 2019. Penerapan minapadi untuk mendukung ketahanan pangan dalam meningkatkan kesejahteraan masyarakat Desa Koto Benai Kabupaten Kuantan Singingi. Unri Conference Series: Community Engagement 1: 304-309 https://doi.org/10.31258/unricsce.1.304-309

(C) 2019 Authors

Peer-review under responsibility of the organizing committee of Seminar Nasional Pemberdayaan Masyarakat 2019 


\section{PENDAHULUAN}

Sektor pertanian banyak memiliki manfaat bagi masyarakat Indonesia dan negara lain karena mayoritas masayarakat Indonesia bermata pencaharian sebagai petani, komoditas pertanian berpengaruh terhadap status gizi dan kesehatan penduduk terutama melalui produksi pangan yang dikonsumsinya. Pangan yang dimaksud meliputi nabati (dari tumbuhan) dan hewani. Dengan kata lain komoditas pertanian merupakan sumber pangan bagi manusia yang akan memberikan zat gizi yang bermanfaat bagi permbuhan dan kesehatan masyarakat. Pada umumnya setiap lahan padi sawah di Indonesia hanya bisa digarap satu sampai dua kali setahun. Waktu yang dibutuhkan dari persemaian benih hingga panen sekitar 4 sampai 5 bulan.

Kabupaten Kuantan Singingi merupakan salah satu kabupaten yang ada di Provinsi Riau, di kabupaten ini sebagian penduduknya bermata pecaharian dibidang pertanian. Salah satu desa yang menghasilkan padi adalah Desa Koto Benai. Luas tanah persawahan di Desa Koto Benai yaitu 2,5 ha. Masyarakat Desa Koto Benai menanam tanaman padi hanya $1 \mathrm{kali}$ dalam satu tahun. Sementara per periode permusiman tanam hingga panen padi adalah 4-5 bulan pertahun sehingga masa istirahat lahan sawah mencapai 3 - 4 bulan dalam satu tahun. Hal tersebut mengakibatkan para petani tidak mendapatkan penghasilan sebelum waktu panen selanjutnya tiba.

Salah satu upaya yang dikembangkan dalam memanfaatkan waktu luang lahan yaitu dengan usaha tani mina padi. Mina padi merupakan cara pemeliharaan ikan di sela-sela tanaman padi, sebagai penyelang diantara dua musim tanam padi atau pemeliharaan ikan sebagai pengganti palawija di persawahan dengan sistem irigasi yang baik misalnya irigasi teknis. Pemeliharaan ikan pada usaha tani terpadu antara lain menambah pendapatan, perkembangan ekonomi masyarakat, memperkaya media tanam dengan pupuk organik dan meningkatkan produksi plankton yang menjadi sumber makanan bagi ikan (Susanto, 2006).

Budidaya mina padi adalah budidaya terpadu yang dapat meningkatkan produktivitas lahan sawah, yaitu selain tidak mengurangi hasil padi, juga dapat menghasilkan ikan. Lahan sawah menjadi subur dengan adanya kotoran ikan yang mengandung berbagai unsur hara, sehingga dapat mengurangi penggunaan pupuk. Ikan dapat juga membatasi tumbuhnya tanaman lain yang bersifat kompetitor dengan padi dalam pemanfaatan unsur hara, sehingga dapat juga mengurangi biaya penyiangan tanaman liar.

Organisasi Pangan dan Pertanian PBB (FAO) menilai program minapadi sebagai tiga kemenangan karena berhasil memberdayakan praktik pertanian dengan komoditas sektor kelautan dan perikanan. Tiga kemenangan tersebut adalah dapat meningkatkan panen, meningkatkan pendapatan, serta memperbaiki nutrisi yang berasal dari hasil panen beras dan ikan (Anonim, 2016). Melalui budidaya minapadi, produktivitas sawah akan meningkat baik dari padi yang dihasilkan maupun tambahan pendapatan dari ikan/udang, sehingga kebutuhan gizi masyarakat terpenuhi, kesejahteraan petani dan produktivitas lahan meningkat serta mendukung kedaulatan pangan.

Petani Desa Koto Benai ingin meningkatkan intensitas penggunaan lahan dengan menerapkan usaha tani mina padi dan sebagai pemanfaatan masa bera atau masa rehat lahan pasca panen padi sebagai pengganti palawija untuk meningkatkan pendapatan. Akan tetapi para petani dan masyarakat sekitar belum mengetahui bagaimana cara pelaksanaan kegiatan budidaya mina padi itu sendiri. Diharapkan dengan dilakukannya kegiatan pengabdian ini masyarakat khususnya para petani dapat memahami teknik pemiliharaan ikan dengan sistem minapadi, sehingga setelah diadakannya pengabdian ini para petani dan masyarakat dapat menerapkan teknologi sistem minapadi ini sehingga dapat meningkatkan pendapatan petani yang tidak hanya berasal dari hasil pertanian saja tetapi juga dari hasil peternakan yaitu ikan.

\section{MASALAH}

Ada beberapa permasalahan yang teridentifikasi di lokasi pengabdian, antara lain yaitu para petani Desa Koto Benai ingin meningkatkan intensitas penggunaan lahan dengan menerapkan usaha tani mina padi, dengan lahan Persawahan yang tidak terpakai setelah pasca panen. Kemudian bagaimana memberdayakan masyarakat dalam meningkatkan pendapatan selain dari hasil sawah serta bagaimana meningkatkan pengetahuan masyarakat tentang Pelaksanaan minapadi.

\section{METODE}

Metode pelaksanaan kegiatan pengabdian berdasarkan masalah prioritas mitra maka akan dilaksanakan kegiatan berupa: Survey, Sosialisasi, Pelatihan, Pembuatan Demplot dan Pendampingan Pelaksanaan Penerapan teknologi minapadi kolam dalam di lokasi mitra. Survey dilakukan untuk menghimpun informasi baik dari instansi terkait maupun dari calon mitra dan dari sumber lainnya. Sosialisasi bertujuan memberikan 
penjelasan mengenai maksud dan tujuan pelaksanaan program serta memberikan paparan hasil studi banding yang telah dilakukan tim pelaksana ke Kabupaten Kuantan Singingi.

Pelatihan penerapan teknologi minapadi kolam dalam kepada kelompok tani dan petani sasaran, melalui pemberian materi dan praktek di lapangan. Pembuatan Demplot bertujuan untuk memberikan fasilitas pembelajaran bagi mitra dalam menerapkan teknologi minapadi kolam dalam. Pendampingan, bertujuan untuk membimbing dan mengarahkan petani mitra dilapangan selama proses budidaya sampai panen serta dapat digunakan sebagai sarana evaluasi dalam pelaksanaan program. Adapun evaluasi tiap tahapan dilakukan untuk mengumpulkan informasi dari para mitra, sehingga diharapkan program berjalan dengan baik dan sesuai dengan kebutuhan mitra Solusi yang ditawarkan dan metode pelaksanaan Rincian dari tahapan pelaksanaan kegiatan sebagai berikut: Survey Sosialisasi Pelatihan Pembuatan Demplot Pendampingan Evaluasi dan Pelaporan. Metode yang digunakan dalam penyuluhan ini yaitu dengan metode ceramah dan praktek langsung.

\section{Langkah 1. Metode Ceramah (Materi)}

Metode ceramah yang akan di sampaikan oleh tim pengabdian secara bergantian, metode ini dipilih untuk menyampaikan konsep tentang teknologi sistem minapadi. Penggunaan metode ceramah dikombinasikan dengan memanfaatkan laptop dan LCD untuk menayangkan materi powerpoint yang dilengkapi dengan gambar-gambar.

Pemanfaatan laptop dan LCD untuk membantu peserta lebih mudah memahami tentang bahaya pencemaran limbah plastik, mengingat materi relatif banyak dan waktu pelatihan yang terbatas. Setelah metode ceramah dilanjutkan dengan praktek langsung contoh teknologi minapadi. Dengan dilakukannya praktek langsung teknologi sistem mina padi ini masyarakat diharapkan sehingga dapat menerapkan sistem pemeliharaan minapadi ini.

\section{Langkah 2. Praktek Contoh Pelaksanaan Teknologi Penerapan Minapadi}

Setelah Tim Pengabdian memberikan materi mengenai Minapadi, Praktek pelaksanaan Teknologi Minapadi inipun dilaksanankan. Tim pengabdian melakukan praktek langsung dilapangan mulai dari memasang jaring, penebaran benih ikan sebanyak 1000 ekor dengan ukuran 1-3 cm ini mengacu kepada Sadele (1989) mengenai kepadatan penebaran benih ikan untuk sistem minapadi dan juga memberikan pengarahan mengenai pemberian pakan yang baik kepada para petani.

\section{HASIL DAN KETERCAPAIAN SASARAN}

Pengabdian masyarakat ini telah selesai dilakukan. Pengabdian ini memberikan manfaat bagi mitra tani dari aspek permasalahan sebelum pengabdian masyarakat ini dilakukan. Karena metode mina padi mampu meningkatkan produktivitas lahan pertanian tidak dibiarkan selama pasca panen serta meningkatkan pendapatan petani. Sebelum melakukan pengabdian Tim mempersiapkan ruangan dengan memasang spanduk yang bertemakan judul kegiatan pengabdian ini (Gambar 1). Dalam kegiatan pengabdaian ini masyarakat dan khususnya para petani sangat antusias mengikuti acara ini (Gambar 3).

Berdasarkan hasil kegiatan pengabdian kepada masyarakat yang telah dilakukan dapat diketahui bahwa masyarakat masih perlu meningkatkan pemahaman budidaya mina padi. Mina Padi merupakan cara pemeliharaan ikan disela-sela tanaman padi, sebgaai penyelang diantara dua musim tanam padi, atau pemeliharaan ikan sebagai pengganti palawija dipersawahan. Dalam kegiatan pengabdian sistem mina padi di Desa Koto Benai ini pemelihaaran ikan diletakkan embung yang airnya mengalir ke persawahan. Terdapat perbedaan antara satu daerah dengan daerah yang lain dalam menerapkan sistem minapadi ini. Untuk mina padi di Desa Koto Benai ini tidak bisa langsung diterapkan di persawahan karena tekstur dari tanahnya yang keras. Jadi ikan di letakkan di embung yang airya mengalir ke sawah.

Menurut Sasa et al. (2003) terdapat perbedaan antara satu daerah dengan daerah-daerah yang lain dalam menerapkan sistem minapadi ini. Hal ini sangat bergantung pada ketersediaan irigasi di daerah tersebut, benih ikan yang tersedia dengan kualitas yang bagus, adanya pasar yang mendukung untuk pemasaran produk ikan dan padi yang dihasilkan, curah hujan dan aspek sosial ekonomi masyarakat. Seperti yang dikemukakan oleh Nurhayati et al. (2016), pengolahan minapadi ini memanfaatkan kearifan lokal yang sudah ada di suatu daerah, dengan cara memanfaatkan unsur-unsur yang ada di alam. Selain kesesuaian lahan, jaringan irigasi merupakan faktor penting yang mempengaruhi keberhasilan sistem minapadi (Cahyaningrum et al., 2014). Lantarsih (2012) berpendapat bahwa jenis tanah yang baik yang digunakan dalam sistem minapadi adalah tanah yang sifatnya tidak porous, yaitu tanah lempung. Perubahan iklim yang terjadi saat ini membuat sistem minapadi sebagai pilihan yang bijak dalam mengoptimalkan lahan pertanian padi. 
Kegiatan pengabdian kepada masyarakat ini telah meningkatkan pendapatan masyarakat setempat dari hasil panen ikan yang bisa dipanen 4 kali dalam setahun karena selama 6 bulan pasca panen masa luang untuk menanam benih padi berikutnya. Pada awal pengabdian ini Tim pengabdian menebar bibit ikan nila 1000 ekor dengan ukuran 1- $3 \mathrm{~cm}$. Dengan adanya budidaya ikan di embung ini maka pendapatan masyarakat meningkat dengan hasil panen beras dengan luas 1 ha sawah di desa Koto Benai diperoleh $2000 \mathrm{~kg}$ ( 2 ton) $1 \mathrm{~kg}$ beras dihargai Rp10000 jadi dari hasil penjualan beras masyarakat memperoleh sebanyak Rp 20.000.000 dan dari ikan nila sekali panen di peroleh $160 \mathrm{~kg}$ dengan harga $\mathrm{Rp} 30.000$, maka pendapatan dari ikan sebesar Rp 4.800.000 sehingga total pendapatan petani minapadi dari penjualan beras dan ikan sebesar 24.800 .000 ,- atau meningkat sebesar $24 \%$ dibandingkan jika mereka hanya menanam padi dan membiarkan ternak disana.

Dengan sistem mina padi ini dapat meningkatkan produksi tanaman padi, karena sistem tanam mina padi ini memberikan manfaat dapat meningkatkan kesuburan tanah yang berasal dari kotoran ikan yang terbawa ke persawahan sehingga dapat mengurangi penggunaan pupuk. Serta dengan sistem mina padi maka efisiensi dan produktivitas lahan lebih meningkat.

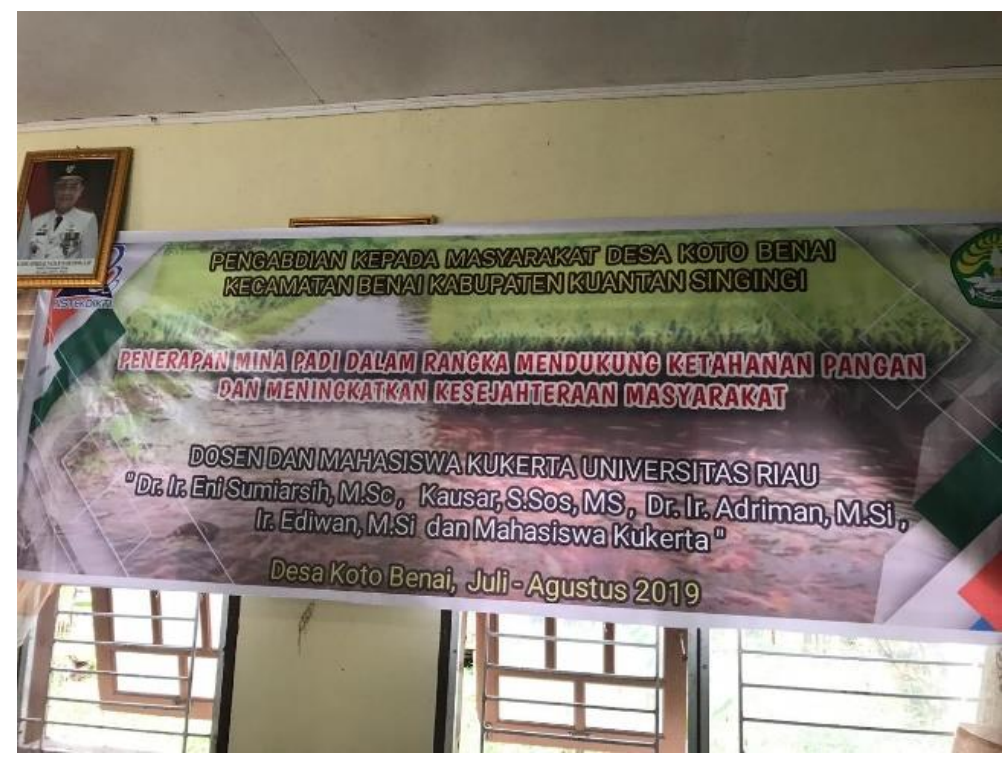

Gambar 1. Persiapan kegiatan pengabdian masyarakat

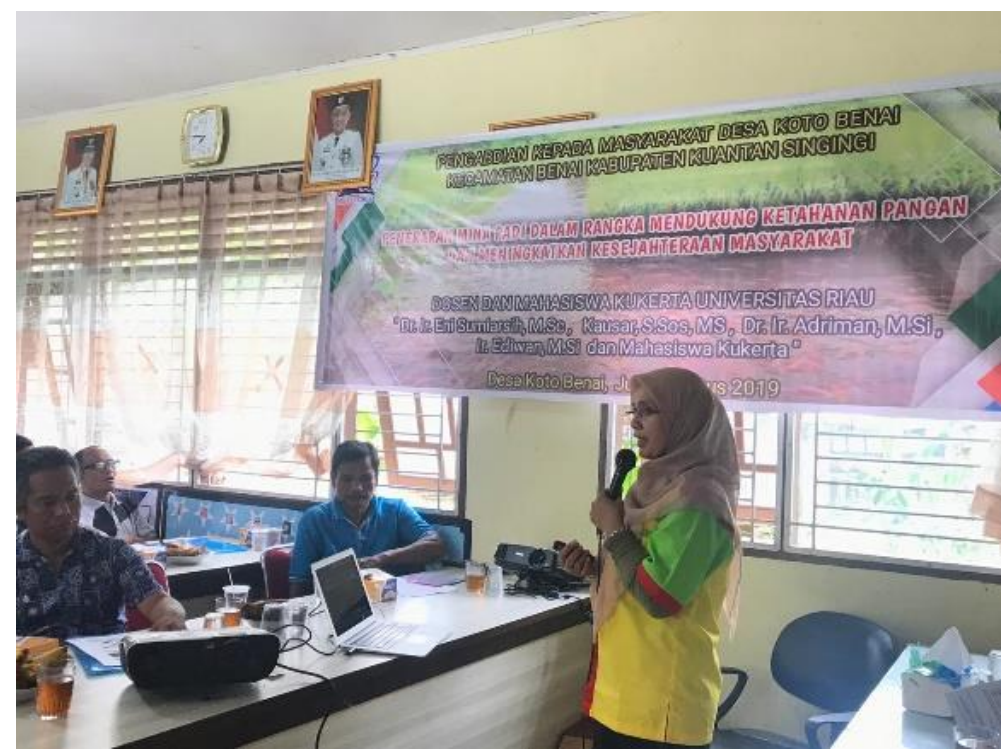

Gambar 2. Pemaparan Materi 


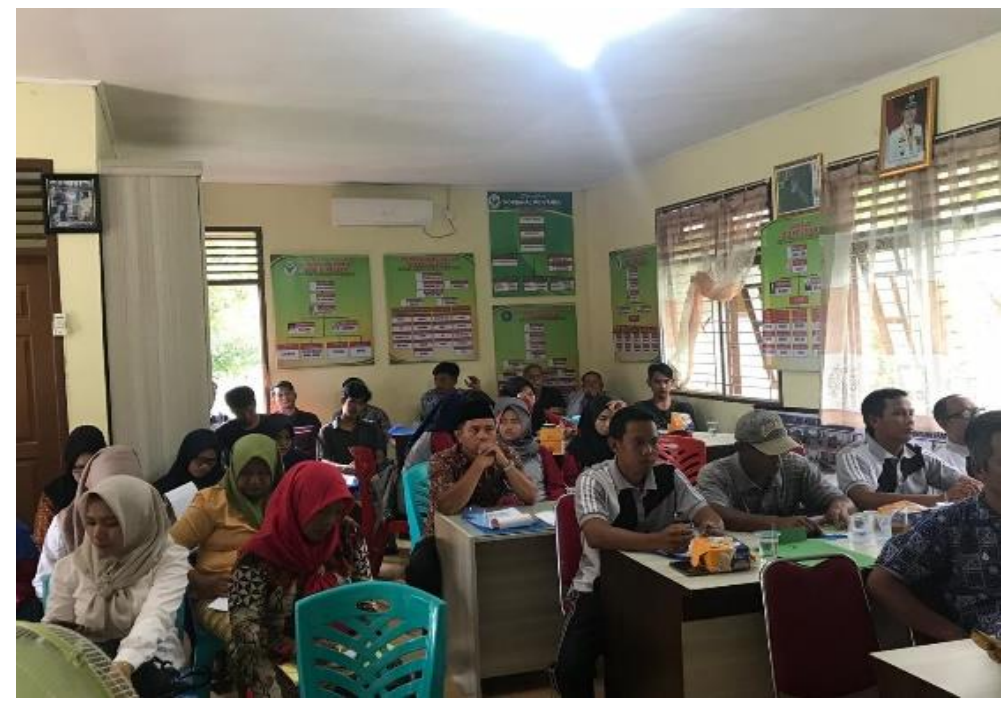

Gambar 3. Antusiasme Masyarakat saat pelatihan mina padi

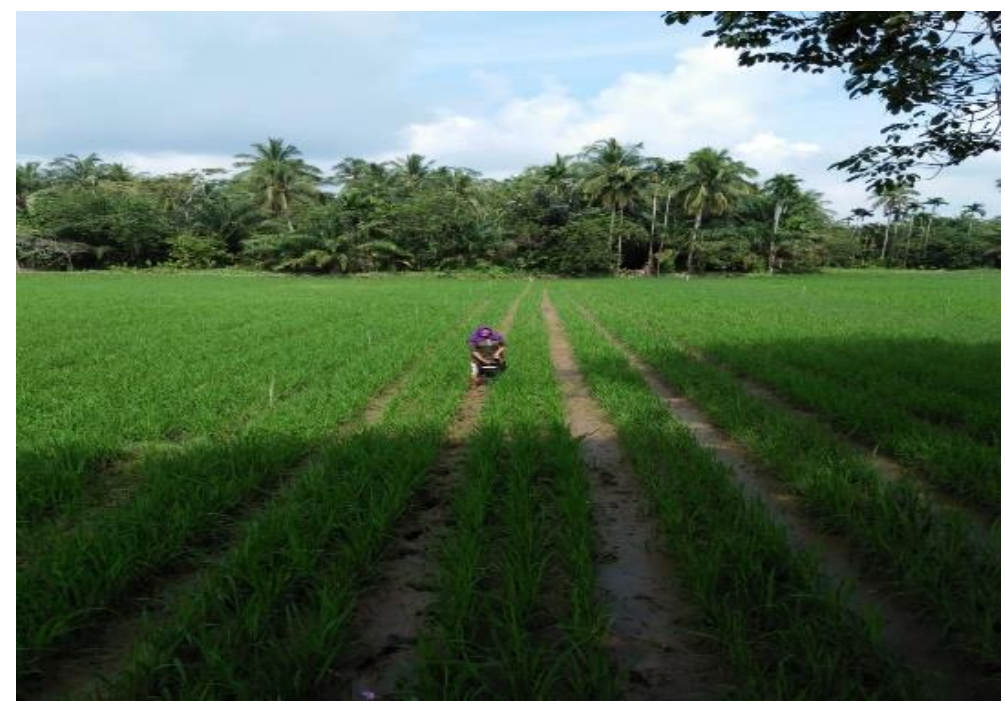

Gambar 4. Sawah Desa Koto Benai pada saat musim tanam

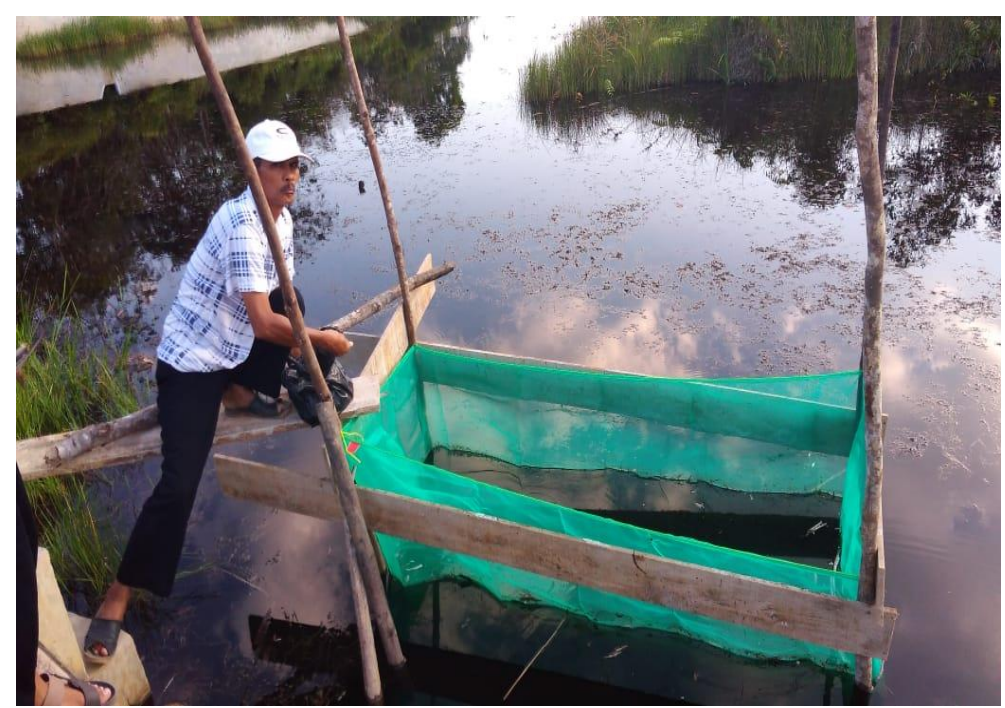

Gambar 5. Tempat benih ikan-ikan Nila mina padi 
Akan tetapi pada kegiatan pengabdian ini tim belum bisa melakukan tebar benih ikan bersamaan dengan penanaman benih padi secara sekaligus seperti sistem minapadi yang ada Pulau Jawa. Karena masyarakat Desa Koto Benai melakukan kegiatan penanaman padi setelah Acara Pacu Jalur sekitar bulan Agustus. Secara umum kegiatan pengabdian ini berlangsung dengan baik dan telah selesai dilaksanakan. Kegiatan ini telah memberikan tambahan pengetahuan tentang Teknik penerapan minapadi bagi masyarakat Desa Koto Benai dan menghaslkan produk yang dapat meningkatkan pendapatan serta meningkatkan status gizi masyarakat Desa Koto Benai dan Indonesia.

\section{KESIMPULAN}

Berdasarkan kegiatan pengabdian kepada masyarakat yang telah dilakukan, petani dan masyarakat Desa Koto Benai sangat antusias dan dapat memahami materi yang disampaikan serta praktek langsung pembuatan mina padi ini. Kegiatan mina padi ini telah menghasilkan ikan nila. Dengan bertambahnya pendapatan masyarakat dari segi ekonomi ini juga dapat meningkatkan status gizi, membuka peluang usaha dan menjaga kelestarian lingkungan.

\section{UCAPAN TERIMA KASIH}

Kegiatan pengabdian kepada masyarakat ini merupakan pengabdian DIPA UNRI yang di Danai oleh LPPM Universitas Riau, kami tim pengabdian mengucapkan terima kasih kepada LPPM Universitas Riau yang telah memberikan bantuan dana sehingga kegiatan ini bisa dialkukan, kami juga mengucapkan terima kasih kepada seluruh pihak-pihak yang telah ikut serta dalam kegiatan pengabdian kepada masyarakat ini.

\section{DAFTAR PUSTAKA}

Anonim. 2016. Buku Mina Padi Mina Murakabi Kerjasama FAO. 2016. Yogyakarta: Kelompok Pembudidaya Ikan (KPI) Mina Murakabi dan FAO.

Cahyaningrum, W., Widiatmaka, dan K. Soewardi. 2014. Arahan Spasial Pengembangan Minapadi Berbasis Kesesuaian Lahan dan Analisis A’WOT di Kabupaten Cianjur, Jawa Barat. Majalah Ilmiah Globe 16(1): 77-88.

Lantarsih, R. 2012. Pengembangan "Minapadi Kolam Dalam" di Kabupaten Sleman. Jurnal Agraris 2(1): 16-27.

Nurhayati, A., W. Lili, T. Herawati, \& I. Riyantini. 2016. Derivatif Analysis of Economic and Social Aspect of Added Value Minapadi (Paddyfish Integrative Farming) a Case Study in the Village of Sagaracipta Ciparay Sub District, Bandung West Java Province, Indonesia. Aquatic Procedia 7: 12-18.

Sadele, S. 1989. Petunjuk Teknis Sistem Usahatani Padi-Ikan. Balai Penelitian Tanaman Pangan Sukamandi. Sukamandi.

Sasa, J. J., S. Partohardjono, \& Fagi, A. M. 2003. Azolla pada Minapadi dan Pengaruhnya terhadap Produktivitas dan Emisi Gas Metan di Lahan Sawah Irigasi. Penelitian Pertanian Tanaman Pangan: 22(2): 86-95. 